\title{
PROTEASES (CASEINASE AND ELASTASE), HEMOLYSINS, ADHESION AND SUSCEPTIBILITY TO ANTIMICROBIALS OF STENOTROPHOMONAS MALTOPHILIA ISOLATES OBTAINED FROM CLINICAL SPECIMENS
}

\author{
Doroti de Oliveira Garcia ${ }^{1,2 *}$; Jorge Timenetsky²; Marina Baquerizo Martinez ${ }^{2,3}$; Waldemar Francisco ${ }^{2,4}$; \\ Sumiko I. Sinto ${ }^{4,5}$; Roberto Mitio Yanaguita ${ }^{2,6}$
}

${ }^{1}$ Laboratório Clínico do Instituto Dante Pazzanese de Cardiologia, São Paulo, SP, Brasil. ${ }^{2}$ Departamento de Microbiologia do Instituto de Ciências Biomédicas da Universidade de São Paulo, São Paulo, SP, Brasil. ${ }^{3}$ Departamento de Análises Clínicas e Toxicológicas da Faculdade de Ciências Farmacêuticas da Universidade de São Paulo, São Paulo, SP, Brasil. ${ }^{4}$ Laboratório Fleury, São Paulo, SP, Brasil. ${ }^{5}$ Seção de Microbiologia, Laboratório Central do Hospital das Clínicas da Faculdade de Medicina da Universidade de São Paulo, São Paulo, SP, Brasil. ${ }^{6}$ Universidade Bandeirantes de São Paulo (UNIBAN), São Paulo, SP, Brasil.

Submitted: November 20, 2000; Returned to authors for corrections: November 29, 2001; Approved: April 08, 2002

\begin{abstract}
Forty-six S. maltophilia isolates obtained from hospital clinical specimens were studied for protease (caseinase and elastase) production, hemolytic activity, adhesion to HEp-2 cells, plastic and glass. Susceptibility to antimicrobial agents was also evaluated. The majority of isolates were obtained from respiratory tract secretions of patients using medical devices. All the isolates grown overnight were able to hydrolyze casein at $30^{\circ} \mathrm{C}$ and $37^{\circ} \mathrm{C}$. After $72 \mathrm{~h}$, all the isolates hydrolyzed elastase at $30^{\circ} \mathrm{C}$ and 40 isolates $(87 \%)$ at $37^{\circ} \mathrm{C}$. Most of the isolates presented hemolytic activity after $96 \mathrm{~h}$ of incubation at both temperatures. Rabbit blood showed the hightest hemolytic activity, after $96 \mathrm{~h} 61 \%$ and $98 \%$ of tested isolates presented $\beta$-hemolysis at $30^{\circ} \mathrm{C}$ and $37^{\circ} \mathrm{C}$, respectively. All isolates were susceptible to trimethoprim-sulfametoxazole and were resistant to most $\beta$-lactams tested. By the dilution method, S. maltophilia showed a high susceptibility to ticarcillin-clavulanate and a lower susceptibility to ciprofloxacin than the agar diffusion. The isolates showed adhesion to HEp-2 cells, plastic and glass. The proteolytic activities and adhesion to inanimate surfaces detected in S. maltophilia can be related to the pathogenesis of this bacterium and/or medical device colonization which favors the development of nosocomial infections.
\end{abstract}

Key words: Stenotrophomonas maltophilia, proteases, elastase, hemolysins, adhesion, antimicrobial agents.

\section{INTRODUCTION}

After a period of uncertain taxonomy, the non-fermentative Gram-negative rod previously known as Pseudomonas maltophilia and Xanthomonas maltophilia has been reclassified as Stenotrophomonas maltophilia (17).

Stenotrophomonas maltophilia is frequently isolated from clinical specimens and is characterized by a negative oxidase reaction, esculin hydrolysis, motility and DNase tests (8). $S$. maltophilia is found in a variety of environments and can be isolated from water, soil, sewage, raw milk, frozen fish, and hospital disinfectant solutions (13). Several hospital environment isolates have been recovered from water faucets, respirators, sinks, catheters and the hands of hospital personnel (18).

S. maltophilia is considered to be an opportunistic pathogen. Nosocomial colonization and infection are the most common occurrences. This specie is frequently cultured as transient flora from hospitalized patients, but is also able to cause bacteremia, septicemia, endocarditis, conjunctivitis,

\footnotetext{
* Corresponding author. Mailing address: Seção de Bacteriologia do Instituto Adolfo Lutz, Av. Dr. Arnaldo, 351, Cerqueira César. 01246-902, São Paulo, SP, Brasil. Phone: (+5511) 3068-2896, Fax: (+5511) 3085-3505. E-mail: dogarcia@yahoo.com.br
} 
mastoiditis, meningitis, postoperative wounds, abscesses, urinary tract infections and pneumonia $(7,9,12,21)$.

This microorganism is becoming an important nosocomial pathogen $(6,13,22)$ and has an intrinsic resistance to most of $\beta$-lactam antimicrobial agents. When $S$. maltophilia is isolated from patients with underliyng defficiencies in host defense mechanisms, there is convincing evidence for its potential pathogenicity (21). However, little is known about virulence factors associated with this microorganism $(6,18)$.

The majority of the isolates produce several extracellular enzymes, such as cytolitic toxins (hemolysins), lipases, chitinases, hyaluronidases, mucinases and proteases, including elastase (18). The expression of elastase is variable and correlated with the virulence of $S$. maltophilia (3).

Considering these characteristics, this study presents the detection of proteolytic (casein and elastase) and hemolytic activity, adhesion to HEp-2 cells, to plastic and to glass, and antimicrobial susceptibility of clinical isolates of $S$. maltophilia isolated from four medical centers in the city of São Paulo, SP, Brazil.

\section{MATERIALS AND METHODS}

\section{Microorganisms}

Forty-three $S$. maltophilia isolates were obtained from clinical specimens of patients from the Dante Pazzanese Institute of Cardiology, the Clinical Hospital of São Paulo and the University Hospital, São Paulo, Brazil. Three isolates were obtained from non-hospitalized patients at Fleury Laboratory, São Paulo, Brazil. Thirty-two (70\%) of these isolates were obtained from respiratory tract secretions (the majority obtained from intubed patients in Post-operatory Unit), five (10\%) from post-operative wounds, three (7\%) from urine, three $(7 \%)$ from catheters, one $(2 \%)$ from blood, one $(2 \%)$ from cerebral spinal fluid (CSF), and one (2\%) from vaginal secretion. Clinical manifestations are listed in Table 1. The microorganisms were identified by biochemical tests, such as oxidation of glucose and lactose, oxidase reaction, growth on MacConkey agar, esculin hydrolysis, motility and DNase

Table 1. Clinical manifestations of S. maltophilia obtained from clinical specimens.

\begin{tabular}{cc}
\hline Clinical manifestations & Number of strains \\
\hline Pneumonia & $30(65 \%)^{1}$ \\
Urinary infections & $3(7 \%)^{2}$ \\
Meningitis & $1(2 \%)^{2}$ \\
Cervicitis & $1(2 \%)^{2}$ \\
Other & $11(24 \%)$ \\
\hline
\end{tabular}

1- in 19 cases - S. maltophilia was the sole isolate;

2- S. maltophilia was the sole isolate.
(Difco Laboratories, Detroit, Michigan, USA) (8), just to confirm the previous identification. The isolates were stored at $-20^{\circ} \mathrm{C}$ in 2 YT Broth (Difco Laboratories, Detroit, Michigan, USA) with glycerol (20). S. maltophilia ATCC 13637 was used as a control.

\section{Casein Hydrolysis}

$S$. maltophilia isolates were previously grown overnight in Tryptic Soy Broth (TSB) at $30^{\circ} \mathrm{C}$ and $37^{\circ} \mathrm{C}$. The isolates were inoculated on nutrient agar (Difco Laboratories, Detroit, Michigan, USA) with $0.3 \%$ of casein (Sigma) and incubated overnight at $30^{\circ} \mathrm{C}$ and $37^{\circ} \mathrm{C}$ (several concentrations of casein were previously tested, data not published). Casein hydrolysis was visualized by the application of $30 \%$ tricloroacetic acid on the agar surface. A transparent halo around the bacterial growth was considered as being a positive reaction. Strains of Bacillus subtilis and Escherichia coli ATCC 25922 were used as positive and negative controls, respectively.

\section{Elastin Hydrolysis}

Plates with nutrient agar (meat extract, peptone and Noble Agar) (Difco Laboratories, Detroit, Michigan, USA) - elastin (Sigma) were prepared as previously described (19). S. maltophilia isolates, previously grown overnight in Bouillon Broth (Merck, Darmstadt, Germany) at 30 and $37^{\circ} \mathrm{C}$, were inoculated by a single streak on elastin-nutrient agar and incubated at $30^{\circ} \mathrm{C}$ and $37^{\circ} \mathrm{C} / 48-72$ hours. The elastase activity was visualized by elastin degradation halos around the bacterial growth. Strains of Pseudomonas aeruginosa ATCC 27853 and E. coli ATCC 25922 were used as positive and negative controls, respectively.

\section{Hemolysins}

S. maltophilia isolates were inoculated on Blood Agar Base plates (Difco Laboratories, Detroit, Michigan, USA) with pig, sheep, bovine, guinea pig or human defibrinated blood at $5 \%$ and incubated at $30^{\circ} \mathrm{C}$ and $37^{\circ} \mathrm{C}$ for 24 to 96 hours. Hemolysis around the bacterial growth was observed.

\section{Adhesion to HEp-2 cells and plastic}

The adhesion assay was based on the technique described by Cravioto (5). HEp-2 cell monolayers were obtained from $10^{5}$ cells inoculated in 4 well disposable microplates (Nunc, Naperville, IL, USA). Bacterial suspensions (1:25) diluted in Minimal Eagle Medium (MEM) were added to the cell monolayers and the system was incubated at $37^{\circ} \mathrm{C}$ for 3 hours. Enteropathogenic E. coli (EPEC) E2348/68 (used as standard for localized adhesion) (2) and Burkholderia cepacia ATCC 25416 were used as positive and negative adhesion controls, respectively.

The adhesion to plastic was done in the same way as the adhesion assay described above, but without HEp-2 cells. 


\section{Adhesion to glass coverslips}

Glass coverslips were dipped in bacterial cultures grown in Tryptic Soy Broth (TSB) (Difco Laboratories, Detroit, Michigan, USA) and incubated at $37^{\circ} \mathrm{C}$ for $3 \mathrm{~h}$. After washed 3 times with phosphate-buffered saline (PBS) (pH 7.2), the coverslips were fixed with methanol and stained with May-Grünwald at $2 \%$ for 5 minutes and by Giemsa for 20 minutes. The glass coverslips were fixed on glass slides and examined by light microscopy.

\section{Agar Diffusion Test}

The antimicrobial susceptibility testing was performed according to standard methodologies (1). The following antimicrobial agents (Cecon, Centro de Controle e Produtos para Diagnóstico Ltda., São Paulo, Brazil) were tested: amikacin $(30 \mu \mathrm{g})$, carbenicillin $(100 \mu \mathrm{g})$, cefoperazone $(75 \mu \mathrm{g})$, cefotaxime $(30 \mu \mathrm{g})$, ceftazidime $(30 \mu \mathrm{g})$, ceftriaxone $(30 \mu \mathrm{g})$, ciprofloxacin $(5 \mu \mathrm{g})$, chloramphenicol $(30 \mu \mathrm{g})$, gentamicin $(10 \mu \mathrm{g})$, imipenem $(10 \mu \mathrm{g})$, netilmicin $(30 \mu \mathrm{g})$, trimethoprim/sulfamethoxazole $(25 \mu \mathrm{g})$ and tobramycin $(10 \mu \mathrm{g})$.

Antimicrobial susceptibility was interpreted following breakpoints for $P$. aeruginosa, according to guidelines from National Committee for Clinical Laboratory Standards (NCCLS) (15).

E. coli ATCC 25922, P. aeruginosa ATCC 27853 and Enterococcus faecalis ATCC 29212 were used as controls.

\section{Agar Dilution Test}

The agar dilution tests were performed according to standard methodologies (14). The following antimicrobial agents were included: ceftazidime (Glaxo), ciprofloxacin (Bayer), chloramphenicol (Searle), imipenem (Prodomis), ticarcillin/clavulanate (Beecham), trimethoprim/ sulfamethoxazole (Roche). Fresh stock solutions were previously prepared and frozen at $-20^{\circ} \mathrm{C}$. Mueller-Hinton (Difco Laboratories, Detroit, Michigan, USA) agar with antimicrobials were used for the susceptibility tests and the interpretations were done in accordance to breakpoints for P. aeruginosa from NCCLS (15).

\section{RESULTS}

All $S$. maltophilia isolates were negative for the oxidase test, grew as lactose negative colonies on MacConkey agar, were motile and hydrolysed both esculin and DNA.

The isolates hydrolyzed casein after overnight incubation at 30 and $37^{\circ} \mathrm{C}$. Elastin hydrolysis (Fig. 1) was dependant on incubation time and temperature. After $48 \mathrm{~h}$ of incubation, 45 isolates grown at $30^{\circ} \mathrm{C}$ and 35 isolates grown at $37^{\circ} \mathrm{C}$ showed elastase activity. After $72 \mathrm{~h}$, all the isolates grown at $30^{\circ} \mathrm{C}$ and 40 isolates grown at $37^{\circ} \mathrm{C}$ presented elastase activity.

The majority of $S$. maltophilia isolates presented hemolytic activity after 96 hours at $30^{\circ} \mathrm{C}$ and $37^{\circ} \mathrm{C}$. $\beta$-hemolysis and rarely $\alpha$-hemolysis on different types of blood are presented in Table 2.

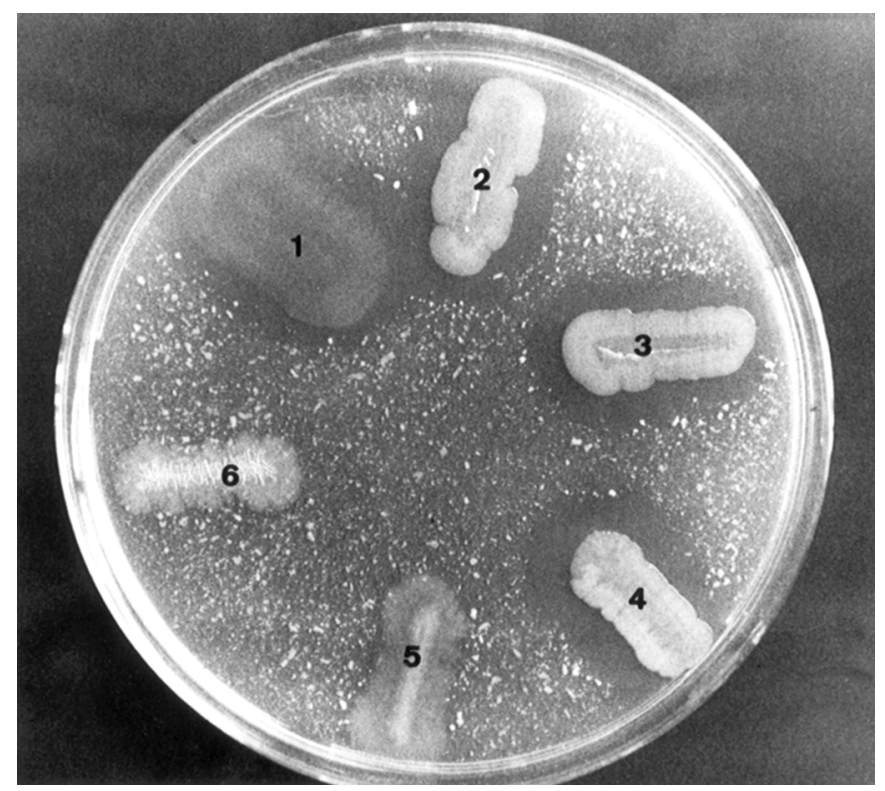

Figure 1. Elastin hydrolysis by bacterial growth on nutrient agarelastin plates. P. aeruginosa (1); S. maltophilia isolated from tracheal secretion - SMDP 92 (2), SMDP 164 (3), SMDP 312 (4) indicating elastase activity; SMDP 315 (5), E. coli (6) elastin particles around bacterial growth indicating non-elastase activity.

Table 2. Frequency and hemolitic activity of $S$. maltophilia isolates, according to the incubation time and temperature, type of blood and hemolysis.

Incubation time and temperature and hemolytic activity*

\begin{tabular}{|c|c|c|c|c|c|c|}
\hline \multirow{3}{*}{$\begin{array}{c}\text { Type } \\
\text { of } \\
\text { blood }\end{array}$} & \multicolumn{3}{|c|}{$30^{\circ} \mathrm{C}$} & \multicolumn{3}{|c|}{$37^{\circ} \mathrm{C}$} \\
\hline & $48 \mathrm{hs}$ & $72 \mathrm{hs}$ & 96hs & $48 \mathrm{hs}$ & $72 \mathrm{hs}$ & 96hs \\
\hline & $\mathrm{N}(\%)$ & $\mathrm{N}(\%)$ & $\mathrm{N}(\%)$ & $\mathrm{N}(\%)$ & $\mathrm{N}(\%)$ & $\mathrm{N}(\%)$ \\
\hline Sheep & & & & & & \\
\hline Hur & & & & ( & & \\
\hline Bovi & ( & $0(\mathrm{C}$ & $7(1$ & (0) & $0(0)$ & \\
\hline Pig & $0(0)$ & $5(1$ & 16( & (0) & $2(4$ & $9(18)^{2}$ \\
\hline Guinea pig & $1(2)$ & $8(16)$ & $28(61)$ & $4(8)$ & $21(43)$ & $45(98)$ \\
\hline
\end{tabular}

*-S. maltophilia isolates presented hemolysis type $\beta$, except when indicated;

1 - 2 isolates (4\%) presented $\alpha$ hemolysis;

${ }^{2}-1$ isolate (2\%) presented $\alpha$ hemolysis.

All the S. maltophilia tested showed adhesion to glass, plastic and HEp-2 cells (Fig. 2).

According to the agar diffusion tests, all $S$. maltophilia isolates were resistant to most $\beta$-lactam antimicrobial agents, such as carbenicillin, ceftriaxone and imipenem. One isolate was susceptible to cefotaxime (2\%). All isolates were susceptible to 
trimethoprim/sulfamethoxazole. Most of them were very susceptible to choramphenicol $(91 \%)$, and moderately susceptible to ciprofloxacin (67\%), ceftazidime (37\%) and aminoglycosides such as amikacin (44\%), gentamicin (39\%), netilmicin (54\%) and tobramycin (50\%).

MICs were obtained by the agar dilution method (Table 3). Differences between the results obtained by the two methods were observed. The susceptibility of $S$. maltophilia to choramphenicol and ceftazidime was lower in the agar dilution method than in agar diffusion. The susceptibility to ciprofloxacin was higher in agar diffusion than the agar dilution method; $67 \%$ of $S$. maltophilia isolates were susceptible in agar diffusion and only $28.3 \%$ were susceptible in the agar dilution method. Agar dilution method confirmed the high susceptibility $(100 \%)$ of this microorganism to trimethoprim/sulfamethoxazole and the high resistance (100\%) to imipenem, also detected by the agar diffusion method. Susceptibility to ticarcillin/clavulanate was also high.

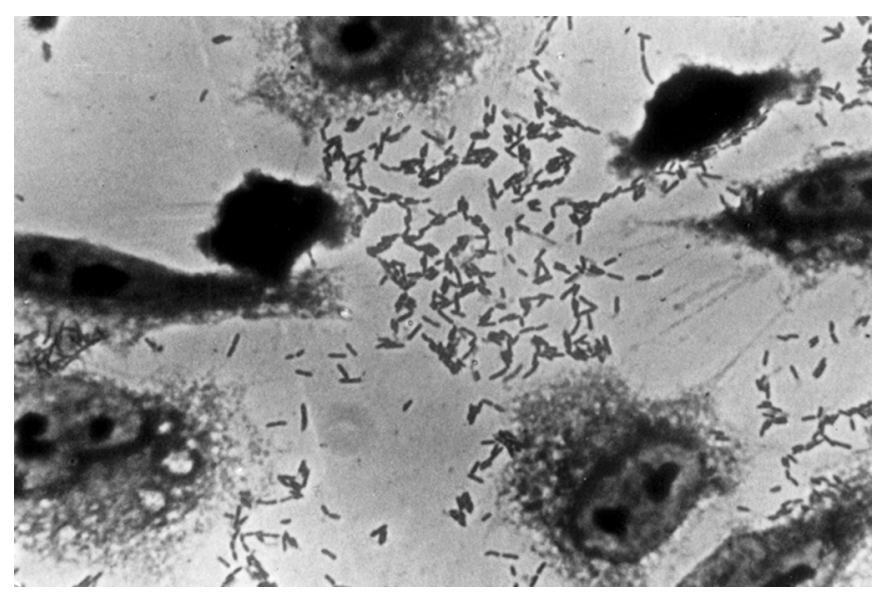

Figure 2. Optical micrographs of $S$. maltophilia adhesion to $\mathrm{HEp}-2$ cells and to plastic after $3 \mathrm{~h}$ of incubation at $37^{\circ} \mathrm{C}$. (x 1.000).

\section{DISCUSSION}

S. maltophilia can be placed in the select group of gram negative rods which cause emerging nosocomial infections. In addition, there is little information about virulence factors of this bacterium.

In this study, of the 30 cases isolated from respiratory tract secretions of patients with pneumonia, $19(63 \%)$ had $S$. maltophilia as the sole isolate. These results indicate that $S$. maltophilia can be important in nosocomial infections.

All S. maltophilia isolates showed elastase activity at $30^{\circ} \mathrm{C}$ after $72 \mathrm{~h}$ and only six isolates, obtained from five cases of pneumonia and one case of skin lesion, did not show elastase activity at $37^{\circ} \mathrm{C}$. After $48 \mathrm{~h}$ of incubation at $30^{\circ} \mathrm{C}$ and $37^{\circ} \mathrm{C}$ the elastase activity was lower than after $72 \mathrm{~h}$. The elastase activity detected in this study was incubation time and temperature dependant.

The results here presented showed a higher percentage of $S$. maltophilia isolates producing elastase than the results described by other authors.

In a study with 20 S. maltophilia clinical and environmental isolates, $60 \%$ presented elastase activity after $48 \mathrm{~h}$ of incubation at $30^{\circ} \mathrm{C}(16)$. In another study, S. maltophilia isolate obtained from a lesion of a patient with gangrenosum ectima presented intense protease activity (caseinase and elastase). However, the isolate obtained from the blood and an isolate from another patient without such a skin lesion did not produce elastase intensively (3).

Fifty-two S. maltophilia isolates from environmental and clinical origin were described as variable on the elastase activity, although this difference was not significant among clinical and environmental isolates (6).

The absence of a standard methodology lead to different results described by the several authors, as mentionated above. Thus, we propose to standardize a methodology to detect

Table 3. Susceptibility of 46 isolates of S. maltophilia, using agar dilution method and MIC breakpoints.

\begin{tabular}{lccccccc}
\hline \multicolumn{1}{c}{$\begin{array}{c}\text { Antimicrobial } \\
\text { agents }\end{array}$} & \multicolumn{3}{c}{$\mathrm{MIC}$} & $\begin{array}{c}\text { MIC breakpoints } \\
\left(\mu \mathrm{g} \mathrm{ml}^{-1}\right)\end{array}$ & \multicolumn{2}{c}{ Susceptibility } \\
\cline { 2 - 8 } & $\begin{array}{c}\mathrm{MIC}_{50}{ }^{\mathrm{a}} \\
\mu \mathrm{g} \mathrm{ml}^{-1}\end{array}$ & $\begin{array}{c}\mathrm{MIC}_{90}{ }^{\mathrm{b}} \\
\mu \mathrm{g} \mathrm{m}^{-1}\end{array}$ & $\mathrm{~S}$ & $\mathrm{R}$ & $\mathrm{S}(\%)$ & $\mathrm{I}(\%)$ & $\mathrm{R}(\%)$ \\
\hline Trimethoprim/Sulfamethoxazole & $0.125 / 2$ & $0.25 / 4$ & $\leq 2 / 38$ & $8 / 152$ & 100 & 0 & 0 \\
Imipenem & $>512$ & $>512$ & $\leq 4$ & $\geq 16$ & 0 & 0 & 100 \\
Chloramphenicol & 8 & 16 & $\leq 8$ & $\geq 32$ & 84.8 & 10.9 & 4.4 \\
Ceftazidime & 16 & 64 & $\leq 8$ & $\geq 32$ & 32.6 & 13 & 54.4 \\
Ciprofloxacin & 2 & 4 & $\leq 1$ & $\geq 4$ & 28.3 & 56.5 & 15.2 \\
Ticarcillin/Clavulanate & $16 / 2$ & $64 / 2$ & $\leq 64 / 2$ & $128 / 2$ & 91.0 & - & 09 \\
\hline
\end{tabular}

${ }^{\mathrm{a}}-\mathrm{MIC}_{50}$, MIC at which $50 \%$ of the isolates are inhibited;

b- MIC $_{90}$, MIC at which $90 \%$ of the isolates are inhibited;

${ }^{c}$ - NCCLS MIC breakpoints $\left(\mu \mathrm{g} \mathrm{ml}^{-1}\right)$ for susceptibility, intermediate susceptibility and resistance. 
elastase activity of S. maltophilia. The methodology of this study was based on the one described by Rust et al. (19), and showed to be very efficient. We observed that the detection of this enzymatic activity was better after $72 \mathrm{~h}$ of incubation at $30^{\circ} \mathrm{C}$.

Hemolytic activity of $S$. maltophilia isolates showed a variety of patterns and was blood type, temperature, and incubation time dependant. Most of the S. maltophilia isolates expressed hemolytic activity only after 96 hours at $30^{\circ} \mathrm{C}$ and $37^{\circ} \mathrm{C}$. Most isolates also showed hemolytic activity on rabbit blood agar $\left(61 \%\right.$ after $96 \mathrm{~h}$ at $30^{\circ} \mathrm{C}$ and $98 \%$ after $96 \mathrm{~h}$ at $\left.37^{\circ} \mathrm{C}\right)$. With the exception of pig blood, all types of blood presented better hemolytic activity, although less intense, at $37^{\circ} \mathrm{C}$. After $48 \mathrm{~h}$ at $30^{\circ} \mathrm{C}, 4 \%$ of S. maltophilia isolates presented hemolysis on human blood agar and $2 \%$ on rabbit blood agar. These data differ from results described in another study (16) in which the hemolysis was observed, after $72 \mathrm{~h}$ of incubation at $30^{\circ} \mathrm{C}$, in $40 \%$ of isolates on pig blood, $60 \%$ on human blood, and $95 \%$ on rabbit blood agar. After $96 \mathrm{~h}$ of incubation at $30^{\circ} \mathrm{C}$, hemolysis was observed in all S. maltophilia isolates on sheep blood and $25 \%$ on bovine blood agar. However, the hemolytic activity restricted to the area under the colony was also considered (16). In this study, such hemolysis was not considered because, after long time of incubation, this effect can be due to bacterial metabolic products.

S. maltophilia isolates showed adhesion to HEp-2 cells, plastic, and glass. The adhesion to HEp- 2 cells suggests that $S$. maltophilia can adhere to other epithelial cells. This may explain the presence of S. maltophilia in the respiratory tract cells. Most isolates were obtained from nosocomial infections which in several cases medical devices were being used by the patients. The adhesion to plastic and glass can represent an important step in the bacterial colonization in immunosupressed patients and/or using medical devices. The adhesion to inert surfaces rarely comes to the attention of investigators interested in the pathogenesis of human infections, except in the colonization of implantable medical devices (4).

Jucker et al. (11) described the adhesion to plastic of $S$. maltophilia isolated from urinary catheter from a patient with a suspicious urinary infection. They demonstrated that this $S$. maltophilia isolate was positively charged.

The susceptibility to antimicrobials from both methodologies showed differences as described in literature (6). There are difficulties in determining the susceptibility of S. maltophilia because the methodologies are not standardized. The diffusion agar method was used because it still is the most commonly used test in clinical laboratories, although not recommended by NCCLS (14). It is important to emphasize the high susceptibility to trimetoprim/sulfamethoxazole and the high resistance to imipenem presented by this group of microorganisms, since the majority of gram negative rods showed opposite results to these antimicrobial agents. In addition, it is important to emphasize that the agar dilution method is the one which offers the most reliable results.

We conclude in this study that the elastase activity is incubation time and temperature dependant. Due to the different results obtained among several authors, we propose to standardize the methodology to detect the elastase activity of S. maltophilia. This bacterium adheres to plastic, glass and on to HEp-2 cells. Trimetoprim/sulfamethoxazole continues being the drug of choice for the treatment of S. maltophilia infections. The microorganism with these characteristics confirms the trends cited that $S$. maltophilia can become an important nosocomial pathogen.

Studies are under progress to characterize external structures that can be responsible for the described adhesions.

\section{ACKNOWLEDGMENTS}

This study was supported by Fundação de Amparo à Pesquisa do Estado de São Paulo (FAPESP) 93/4695-8. We thank Stella Maria Guida for providing the $S$. maltophilia isolates from the Hospital Universitário of the Universidade de São Paulo, São Paulo, SP, Brazil, Dr. Leonard Mayer (Center for Diseases Control - CDC, Atlanta, USA) for providing S. maltophilia ATCC13637 and Burkholderia cepacia ATCC25416 and Cely S.A. Medeiros for sending clinical data of S. maltophilia isolates obtained from patients from Instituto Dante Pazzanese de Cardiologia.

\section{RESUMO}

\section{Proteases (caseinase e elastase), hemolisinas, adesão e sensibilidade a antimicrobianos em cepas de Stenotrophomonas maltophilia isoladas de amostras clínicas}

Quarenta e seis amostras de $S$. maltophilia obtidas de amostras clínicas foram estudadas quanto à produção de protease (caseinase e elastase), atividade hemolítica, adesão a células HEp-2, ao plástico e ao vidro. A sensibilidade aos agentes antimicrobianos também foi avaliada. A maioria das amostras foi obtida de secreções do trato respiratório de pacientes em uso de "dispositivos" médicos. Todas as amostras foram capazes de hidrolisar a caseína após o crescimento a $30^{\circ} \mathrm{C}$ e $37^{\circ} \mathrm{C}$ por $16-18 \mathrm{hs}$. Após $72 \mathrm{hs}$, todas as amostras apresentaram atividade hemolítica após $96 \mathrm{hs}$ de incubação em ambas as temperaturas. A maior atividade hemolítica foi verificada com o sangue de coelho; após $96 \mathrm{hs}, 61 \%$ e $98 \%$ das amostras apresentaram b-hemólise a $30^{\circ} \mathrm{Ce} 37^{\circ} \mathrm{C}$, respectivamente. Todas as amostras foram sensíveis ao sulfametoxazol-trimetoprim e resistentes à maioria dos antimicrobianos b-lactâmicos testados. Através do método de diluição em ágar, S. maltophilia mostrou uma alta sensibilidade à ticarcilina-ácido clavulânico e uma 
menor sensibilidade à ciprofloxacina do que pelo método de difusão em ágar. As amostras mostraram adesão às células HEp-2, ao plástico e ao vidro. A atividade proteolítica e adesão a superfícies inanimadas detectadas em S. maltophilia podem estar relacionadas à patogênese desta bactéria. A colonização de "dispositivos" médicos favorece o desenvolvimento de infecções hospitalares.

Palavras-chave: Stenotrophomonas maltophilia, proteases, elastase, hemolisinas, adesão, agentes microbianos.

\section{REFERENCES}

1. Bauer, A.W.; Kirby, W.M.M.; Sherris, J.C. et al. Antibiotic susceptibility testing by a single disc method. Am. J. Clin. Pathol., 145: 45-495, 1966.

2. Baldini, M.M.; Kaper, J.B.; Levine, M.M.; Candy, D.C.; Moon, H.W. Plasmid-mediated adhesion in enteropathogenic Escherichia coli. J. Pediatr. Gastroenterol. Nutr., 2(3): 534-538, 1983.

3. Bottone, E.J.; Reitano, M.; Janda, M.; Troy, K.; Cuttner, J. Pseudomonas maltophilia Exoenzyme Activity as Correlate in Pathogenesis of Ecthyma Gangrenosum. J. Clin. Microbiol., 24: 995-997, 1986.

4. Christensen, G.D.; Baldassari, L.; Simpson, W.A. Methods for Studying Microbial Colonization of Plastics. Methods Enzimol., 253: 477-500, 1995.

5. Cravioto, A.; Gross, R.J.; Scotland, S.M.; Rowe, B. An adhesive factor found in strains of Escherichia coli belonging to the tradicional infantile enteropathogenic serotypes. Curr. Microbiol., 3: 95-99, 1979.

6. Denton, M.; Kerr, K.G. Microbiological and Clinical Aspects of Infection Associated with Stenotrophomonas maltophilia. Clin. Microbiol. Rev., 11: 57-80, 1998.

7. Fujita, J.; Yamadori, I.; Xu, G.; Hojo, S.; Negayama, K.; Miyawaki, H.; Yamaji, Y.; Takahara, J. Clinical features of Stenotrophomonas maltophilia pneumonia in immunocompromised patients. Respir. Med., 90: 35-38, 1996.

8. Gilardi, G.L. Pseudomonas and Related Genera. In: Ballows A. (eds.). Manual of Clinical Microbiology. American Society for Microbiology, Washington, 1991, p.429-441.
9. Gopalakrishnan, R.; Hawley, B.; Czachor, J.S.; Markert, R.J.; Bernstein, J.M. Stenotrophomonas maltophilia infection and colonization in the intensive care units of two community hospitals: A study of 143 patients. Heart Lung, 28: 134-141, 1999.

10. Jaffar-Bandjee, M.D.; Lazdunski, A.; Bally, M.; Carrère, J.; Chazalette, J.P.; Galabert, C. Production of Elastase, Exotoxin A, and Alkaline Protease in Sputa during Pulmonary Exacerbation of Cystic Fibrosis in Pacients Chronically Infected by Pseudomonas aeruginosa. J. Clin. Microbiol., 33: 924-949, 1995.

11. Jucker, B.A.; Harms, H.; Zehnder, A.J.B. Adhesion of the positively charged bacterium Stenotrophomonas (Xanthomonas) maltophilia 70401 to glass and teflon. J. Bacteriol., 178: 5472-5479, 1996.

12. Julve, R.; Rovira, E.; Belda, A.; Prat, J.; Escoms, R.; Albert, A.; Gonzalvo, F. Espectro clínico de la infección por Stenotrophomonas (Xanthomonas) maltophilia. An. Med. Interna., 15: 476-480, 1998.

13. Marshall, W.F.; Keating, M.R.; Anhalt, J.P.; Steckenberg, J.M. Xanthomonas maltophilia: An emerging nosocomial pathogen. Mayo Clin. Proc., 1097-1104, 1989.

14. National Committee for Clinical Laboratory Standards. Methods for dilution antimicrobial susceptibility tests for bacteria that grow aerobically. Approved Standard M7-A4. National Committee for Clinical Laboratory Standards. Villanova, PA, 1997.

15. National Committee for Clinical Laboratory Standards. Performance standards for antimicrobial disk susceptibility tests - Sixt Edition; Approved Standard. M2-A6. National Committee for Clinical Laboratory Standards. Villanova, PA, 1997.

16. O'Brien, M.; Davis, G.H.G. Enzymatic profile of Pseudomonas maltophilia. J. Clin. Microbiol., 16: 417-421, 1982.

17. Palleroni, N.J.; Bradbury, J.F. Stenotrophomonas, a new bacterial genus for Xanthomonas maltophilia (Hugh, 1980) Swings et al. 1983. Int. J. Syst. Bacteriol., 43: 606-609, 1993.

18. Robin, T.; Janda, J.M. Pseudo-, Xantho-, Stenotrophomonas: an emerging pathogen in search of genus. Clin. Microbiol. News, 18: 9$16,1996$.

19. Rust, L.; Messing, C.R.; Iglewski, B.H. Elastase Assays. Methods Enzimol., 235: 561-562, 1994.

20. Sambrook, J.; Fritsh, E.F.; Maniatis, T. Molecular Cloning - A Laboratory Manual, 2nd Ed. Cold Spring Harbor Laboratory Press, Cold Spring Harbor, NY, 1989.

21. Schock, P.E.; Cunha, B.A. Pseudomonas maltophilia. Infect. Control., 4: 169-172, 1987.

22. Yao, J.D.C.; Louie, M.; Louie, L.; Goodfellow, J.; Simon, A.E. Comparison of E test and agar diluition for antimicrobial susceptibility testing of Stenotrophomonas (Xanthomonas) maltophilia. J. Clin. Microbiol., 33: 1428-1430, 1995. 